\title{
EDITORIAL
}

\section{Retrospect and Prospect}

\author{
George A. Turner*
}

The Asbury Seminarian began this, its twenty-first year of publication, with a new cover and new schedule. With this year, 1967, we are introducing four annual numbers:issues for the winter, spring, summer, and fall quarters. The scheduled date for the release of these is January, April, July, and October. We hope you will like the pattern and color of the new cover. It is the result of considerable study on the part of the Seminarian Committee, and especially of our circulation manager, David Edwards, with an artist in California. The design, we trust, is self-explanatory and at the same time reflects the image by which Asbury Seminary seeks to be known-the Cross representing Christ, the dove representing the Holy Spirit, the background of the Fourth Gospel featuring the Word becoming flesh; the world is a reminder of our mission and of the motto of the seminary: "The Whole Bible for the Whole World."

We anticipate that librarians and users of the libraries will welcome the change to four issues per year as an aid in keeping track of the annual issues. Readers of the book reviews and the publishers whose books are reviewed will welcome the added frequency with which these reviews appear: four times a year rather than twice. Many publications of this kind have to be generously subsidized. The disparity between cost of production and the money received from paid subscriptions is such that the very existence of the periodical has at times been in jeopardy. Although the change to four issues per year results in greater cost, it is anticipated that increasing numbers of subscribers will offset this problem. In fact, already we're beginning to see this come to pass. Unchanged is the task to which Asbury Seminary has committed itself since its inception-that of expressing its perspective of "the Wesleyan message in the life and thought of today."

* Professor of Biblical Literature at Asbury Theological Seminary, and Associate Editor of The Asbury Seminarian. 
The subsequent issues of this calendar year will embrace the subjects of church history and theological education. Beginning with this spring number, the periodical will be limited to 48 pages. This again is dictated by economic necessity. Our purpose, however, is to make every word count, something which every publication should keep in mind at a time when books are multiplying. The Editorial Committee is pleased with the new format and we hope our readers will welcome it as well.

\section{THE RELEVANCE OF THE BIBLE}

This spring issue concerns itself with biblical studies. Each of the contributors comes from our own staff, with one of them, Robert Traina, new to us this year. Inclusion of his work will give readers of this journal an opportunity to become better acquainted with him.

Some far-reaching changes have occurred in the past quarter of a century with reference to biblical studies. Biblical scholars who considered themselves up to date, progressive, were earlier inclined to minimize the theological aspect of biblical literature. They were quite willing to agree with the typical historian who failed to see how history and faith could be synchronized. The historian normally distrusted the theologian and suspected him of subjective bias. He considered himself relatively free and objective in his handling of history. Since then influences which can be traced to the continent of Europe and Karl Barth in particular have compelled a recognition of the importance of theology in interpreting the Bible. Today few scholars feel apologetic for reading the Bible from a theological perspective. In other words, the whole science of biblical theology has been revived and given a new degree of respectability. Conversely, historians have come to realize that no historian is truly objective, nor is the student of history objective. Subjective factors play a major role in the writing of history and often in its interpretation as well.

In Bible studies there is an increasing willingness to recognize that the Bible writers were theologians, that even the historical portions of the Bible are actually sacred history, and that the materials were selected with a definite theological purpose in view. This is true in relatively factual portions such as the record of the kings of Israel and Judah and the Gospel according to Mark. There has come a fresh appreciation of the appropriateness of the ancient rabbis in referring to what (te call the historical books of the Old Testament as the work of the "early" prophets."

The question occasionally arises as to the extent to which these ancient scripsufes uage still frelevant in an age which is so 
characterized by science and by a preoccupation with the contemporary issues. It is our conviction that the Bible does not need our defense so much as it needs our presentation. Through the centuries of change this ancient oriental book produced by a group of writers at quite different times and locales continues to impress the world with its importance and relevancy. It is true that many barriers have to be overcome in making its message comprehensible and hence demanding. There are the barriers of time and space, but these barriers have been less formidable than in the past, thanks to our increasing knowledge of the world in which the Bible was written and an increased knowledge of the geography of the lands of the Bible. Due to the dissemination of knowledge facilitated by modern media of communication, the language barrier, always rather formidable, has never been less so than now. To an unprecedented degree readers of the Bible are the beneficiaries of dedicated scholars whose task is to place the language of the ancient scriptures into the most meaningful contemporary idiom. Never before have the scriptures been available to so many people in their own native tongues. Even the "radical theologians" find the scriptures indispensable. Even those who are least inclined to defend the veracity of the scriptures nevertheless find Jesus of Nazareth indispensable in their religious perspective.

The chief claim of the Bible to authority and relevance is the transformation it often makes in the lives and thinking of earnest readers. One of the witnesses to this power and appeal of the scriptures is the eagerness with which residents of South India spend their precious rupees for portions of the Gospels, as reported by World Gospel Mission representatives. Another witness is the effectiveness of the Wycliffe Bible Translators in reaching stone-age tribes with scriptures in their native dialect, as reported in a recent issue of Look magazine (January 24, 1967).

Dean Willard Sperry of Harvard used to relate that as preacher to the university over several decades he had observed that chapel speakers at Harvard who expounded the classic portions of the Bible received a much more appreciative hearing than the more sophisticated expositors who made an effort to "lasso Edington and Jeans" in an effort to make their message more interesting and impressive. The influence of the Bible is further demonstrated by the son of a Methodist clergyman whowas decidedly averse to anything religious. As a student of literature at Harvatd he cautiously enrolled in a literature course which feature the Gospel according to Mark, after being assured that there was "nothing particularly religious" about this course. However, as he was reading the Gospel in connection with the course in English, he became quite absorbed in the story and in the small hours ${ }_{\text {OF ASBURY THEOLOCICAL SEMINARY }}^{\text {B. }}$ 
his roommate and share with him his excitement at the discovery of the vitality of this book. This reading was the means of a transformation of his own life and work. Thus to the sophisticated and the unsophisticated this ancient Semitic book still has the ring of authenticity, authority, and relevance. 